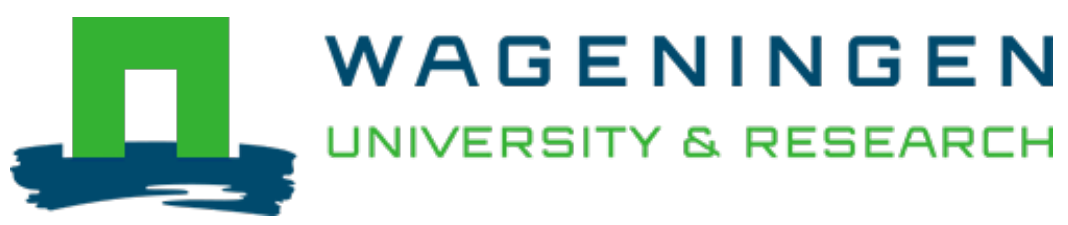

\title{
Warming and eutrophication effects on the phytoplankton communities of two tropical water systems of different trophic states : An experimental approach
}

\author{
Lakes \& Reservoirs : Research and Management
}

Anunciação Gomes, Andreia Maria; Marinho, Marcelo Manzi; Berjante Mesquita, Marcella Coelho; Prestes, Ana Carolina Coelho; Lürling, Miquel et al

https://doi.org/10.1111/lre.12334

This article is made publicly available in the institutional repository of Wageningen University and Research, under the terms of article $25 \mathrm{fa}$ of the Dutch Copyright Act, also known as the Amendment Taverne. This has been done with explicit consent by the author.

Article 25 fa states that the author of a short scientific work funded either wholly or partially by Dutch public funds is entitled to make that work publicly available for no consideration following a reasonable period of time after the work was first published, provided that clear reference is made to the source of the first publication of the work.

This publication is distributed under The Association of Universities in the Netherlands (VSNU) 'Article $25 \mathrm{fa}$ implementation' project. In this project research outputs of researchers employed by Dutch Universities that comply with the legal requirements of Article 25fa of the Dutch Copyright Act are distributed online and free of cost or other barriers in institutional repositories. Research outputs are distributed six months after their first online publication in the original published version and with proper attribution to the source of the original publication.

You are permitted to download and use the publication for personal purposes. All rights remain with the author(s) and / or copyright owner(s) of this work. Any use of the publication or parts of it other than authorised under article $25 \mathrm{fa}$ of the Dutch Copyright act is prohibited. Wageningen University \& Research and the author(s) of this publication shall not be held responsible or liable for any damages resulting from your (re)use of this publication.

For questions regarding the public availability of this article please contact openscience.library@,wur.nl 


\title{
Warming and eutrophication effects on the phytoplankton communities of two tropical water systems of different trophic states: An experimental approach
}

\author{
Andreia Maria da Anunciação Gomes ${ }^{1,2}$ | Marcelo Manzi Marinho ${ }^{3}$ | \\ Marcella Coelho Berjante Mesquita ${ }^{3}$ | Ana Carolina Coelho Prestes ${ }^{3}$ | \\ Miquel Lürling $^{4,5}$ | Sandra M. F. O. Azevedo ${ }^{1}$ (D)
}

${ }^{1}$ Laboratório de Ecofisiologia e Toxicologia de Cianobactérias, IBCCF ${ }^{\circ}$, Universidade Federal do Rio de Janeiro, Rio de Janeiro, Brazil

${ }^{2}$ Instituto Federal do Rio de Janeiro, Niterói, RJ, Brazil

${ }^{3}$ Laboratório de Ecologia e Fisiologia do Fitoplâncton, Departamento de Biologia Vegetal, Universidade do Estado do Rio de Janeiro, Rio de Janeiro, Brazil

${ }^{4}$ Aquatic Ecology and Water Quality Management Group, Department of Environmental Sciences, Wageningen University, Wageningen, The Netherlands

${ }^{5}$ Department of Aquatic Ecology, Netherlands Institute of Ecology (NIOOKNAW), Wageningen, The Netherlands

Correspondence

Sandra M. F. O. Azevedo, Laboratório de Ecofisiologia e Toxicologia de Cianobactérias, IBCCF ${ }^{\circ}$, Universidade Federal do Rio de Janeiro, CCS BI.G, 21941 902, Rio de Janeiro, Brasil.

Email: sazevedo@biof.ufrj.br

Funding information CAPES (Brazil)/NUFFIC (The Netherlands) Grant/Award Number: project 045/2012; Fundação Carlos Chagas Filho de Amparo à Pesquisa do Estado do Rio de Janeiro, Grant/Award Number: proc. E-26/102.863/2011

\begin{abstract}
Both global warming and eutrophication are predicted to promote cyanobacterial blooms. At the same time, how tropical phytoplankton communities exhibiting different trophic state systems will respond to temperature variations is less clear. To investigate the effects of temperature changes and nutrient additions on phytoplankton communities, and gain insights regarding possible resistance to these effects, the present study focused on testing the hypothesis that temperature variations and nutrient additions will have a stronger effect on cyanobacteria dominance in eutrophic water system than in oligo-mesotrophic water systems. Experiments were conducted with phytoplankton communities from two aquatic ecosystems exhibiting different trophic states. To this end, water samples from a eutrophic and oligo-mesotrophic system were collected and incubated at 25 and $30^{\circ} \mathrm{C}$. Samples receiving additional surplus nitrogen $(\mathrm{N})$ and phosphorus $(\mathrm{P})$ inputs were included to serve as eutrophication treatments. The study results indicated that temperature variations alone did not promote cyanobacteria in water from either the oligo-mesotrophic or eutrophic water system. However, nutrient enrichment of the water from the eutrophic system significantly boosted the cyanobacteria, with the biomass increasing by factor of 10 for both the $25^{\circ} \mathrm{C}$ and $30^{\circ} \mathrm{C}$ treatments. In contrast, eutrophication of the water from the oligo-mesotrophic system did not change the relative contribution of phytoplankton groups, with the response ratios being much lower than those for the water from the eutrophic system. Although based on a simple experimental design, the results of the present study suggest that cyanobacteria dominance is favoured by further nutrient additions for eutrophic water systems, independently of any direct temperature effects, and that more pristine environments possess some resistance against eutrophication effects. Since global warming is assumed to indirectly intensify eutrophication symptoms, the results of the present study underscore the importance of nutrient control.
\end{abstract}


KEYWORDS

cyanobacterial blooms, eutrophic systems, global warming, nutrients addition, oligo-

mesotrophic systems

\section{1 | INTRODUCTION}

Human activities are causing severe alterations in ecosystems on a global scale, with freshwater ecosystems being particularly rapidly transformed (Carpenter et al. 1992). These systems have experienced altered precipitation patterns, more intense and longer periods of thermal stratification, modified hydrology, elevated carbon dioxide concentrations, increased nutrient loadings and elevated temperatures as a consequence of global climate change (Carey et al. 2012; Paerl and Huisman, 2008). Further, these changes will probably be intensified in the next decades following both the expected increase in global temperatures and inputs of anthropogenic nutrients (O'Neil et al. 2012). Phytoplankton, as the primary producers of aquatic ecosystems, can be considered a target to experience these environmental changes since nutrient availability and temperature are among the main conditions driving their competitive advantage and regulating phytoplankton species distribution (De Senerpont Domis et al. 2007). Some studies indicate increasing nutrients and temperatures may exert a synergistic effect on cyanobacteria dominance (Jöhnk et al. 2008; Paerl and Paul, 2012). Indeed, of all of potential environmental drivers behind cyanobacterial blooms, the one receiving the most attention among the scientific community is anthropogenic eutrophication. Nutrient availability, mainly nitrogen and phosphorus, has been indicated as a primary factor in the expansion of blooms (Conley et al. 2009). The direct and indirect effects of temperature, however, also have been associated with phytoplankton composition changes, especially indicating that cyanobacteria are more favoured by elevated temperature than are eukaryote competitors (Jöhnk et al. 2008; Paerl and Huisman, 2008, 2009).

Different studies have reported that the global temperature during the current century is expected to increase an additional 1.5 to $5^{\circ} \mathrm{C}$ above today's mean level by 2100 (Hansen et al. 2000) and anthropogenic nutrients inputs will have doubled by 2050 (Tilman and Lehman, 2001). Recent observations have demonstrated the effects of climate warming and eutrophication in U.S. lakes are dependent on their trophic state (Rigosi et al. 2014). Nutrients played a role in oligotrophic lakes, while temperature was important for mesotrophic lakes, with the interactions between these two factors only important in eutrophic and hyper-eutrophic systems (Rigosi et al. 2014). To date, most information about the possible effects of global change on freshwater ecosystems has been based on temperate lake systems (De Senerpont Domis et al. 2013), which emphasizes an urgent need for more data on understudied tropical lake systems.

In this context, the objective of the present study was to examine the effect of temperature alone, and in combination with high nutrient additions, on phytoplankton communities from tropical ecosystems exhibiting two different trophic states. The hypotheses being tested were as follows: (a) temperature variations favour cyanobacteria growth more than that of eukaryote competitors, (b) temperature variations will have a stronger effect on cyanobacteria dominance in tropical eutrophic water than in oligo-mesotrophic water, and (c) nutrient addition will exhibit a stronger effect on favouring cyanobacteria in oligo-mesotrophic water systems than eutrophic water systems.

\section{2 | METHODS AND MATERIALS}

\subsection{Evaluation of the effect of temperature variations and eutrophication on tropical phytoplankton communities}

To evaluate the effects of temperature variations and nutrient additions on phytoplankton communities in tropical ecosystems of different trophic states, water samples were collected from an eutrophic system (Jacarepaguá Lagoon) and from an oligo-mesotrophic system (Samuel Reservoir). Jacarepaguá Lagoon is a water body located near the metropolitan area of Rio de Janeiro in southeast Brazil. It is a shallow, oligohaline lagoon (Gomes et al. 2009). This system has undergone a eutrophication process over the last 30 years (SaiegFilho, 1986). The occurrence of cyanobacterial blooms has also been reported frequently over the past 20 years, with a predominance of Microcystis aeruginosa (Ferrão-Filho et al. 2002; Gomes et al. 2009), including the occurrence of toxic strains (Magalhães et al. 2001). Samuel Reservoir is located $52 \mathrm{~km}$ from the city of Porto Velho, the capital of Rondônia State in the west Amazon region of Brazil. It has a flooded area of $584.26 \mathrm{~km}^{2}$, a flow rate of $265 \mathrm{~m}^{3 /} \mathrm{s}$ and a water residence time of 105 days. Cyanobacteria dominance was already registered in this system, represented by the species Aphanocapsa holsatica, Microcystis panniformes and Merismopedia tenuissima (Nascimento, 2012). Table 1 summarizes more characteristics of these two study areas.

Five litres of water was collected from these two systems, with experiments conducted with $100 \mathrm{ml}$ aliquots of non-filtered water transferred to $200 \mathrm{ml}$ Erlenmeyer flasks and incubated at 25 and $30^{\circ} \mathrm{C}$, with and without nutrient additions. The lower temperature $\left(25^{\circ} \mathrm{C}\right)$ tested was chosen on the basis of the annual average temperature in the water body from southeast Brazil, with the highest temperature $\left(30^{\circ} \mathrm{C}\right)$ considered an increase of $5^{\circ} \mathrm{C}$ of the annual mean temperature predicted by IPCC (2013) as a result of global warming.

Eutrophication was simulated by the addition of nitrogen (7.0 mg N/L as $\mathrm{NaNO}_{3}$ ) and phosphorus (0.8 mg P/L as $\mathrm{K}_{2} \mathrm{HPO}_{4}$ ) 
TABLE 1 Characteristics of study reservoirs

\begin{tabular}{|c|c|c|}
\hline PARAMETER & $\begin{array}{l}\text { SAMUEL RESERVOIR } \\
\text { Oligo-mesotrophic system }\end{array}$ & $\begin{array}{l}\text { JACAREPAGUÁ LAGOON } \\
\text { Eutrophic system }\end{array}$ \\
\hline Coordinates & $08^{\circ} 45^{\prime} \mathrm{S}$ and $63^{\circ} 26^{\prime} \mathrm{W}$ & $22^{\circ} 55^{\prime} \mathrm{S}$ and $43^{\circ} 17^{\prime} \mathrm{W}$ \\
\hline Maximum depth (m) & 30 & 1.5 \\
\hline Surface area $\left(\mathrm{km}^{2}\right)$ & 584.26 & 3.7 \\
\hline $\begin{array}{l}\text { Annual mean temperature } \\
\left({ }^{\circ} \mathrm{C}\right)\end{array}$ & 28 & 25 \\
\hline DIN (mg/L) & $0.5^{\mathrm{a}}$ & $1.2^{\mathrm{a}}$ to $2.8^{\mathrm{b}}$ \\
\hline $\mathrm{SRP}(\mathrm{mg} / \mathrm{L})$ & $0.08^{a}$ & $0.4^{\mathrm{a}}$ to $0.8^{\mathrm{b}}$ \\
\hline $\begin{array}{l}\text { Predominant cyanobacterial } \\
\text { species }\end{array}$ & $\begin{array}{l}\text { Aphanocapsa holsatica } \\
\text { Microcystis panniformes } \\
\text { Merismopedia tenuissima }\end{array}$ & Microcystis aeruginosa \\
\hline References & Nascimento (2012) & $\begin{array}{l}\text { Magalhães et al. (2001), } \\
\text { Ferrão-Filho et al. (2002) } \\
\text { Gomes et al. (2009) }\end{array}$ \\
\hline
\end{tabular}

Abbreviations: DIN, dissolved inorganic nitrogen; SRP, soluble reactive phosphate.

${ }^{a}$ Annual mean of $2007 / 2008$.

${ }^{\mathrm{b}}$ Annual mean of 2014 (unpublished data).

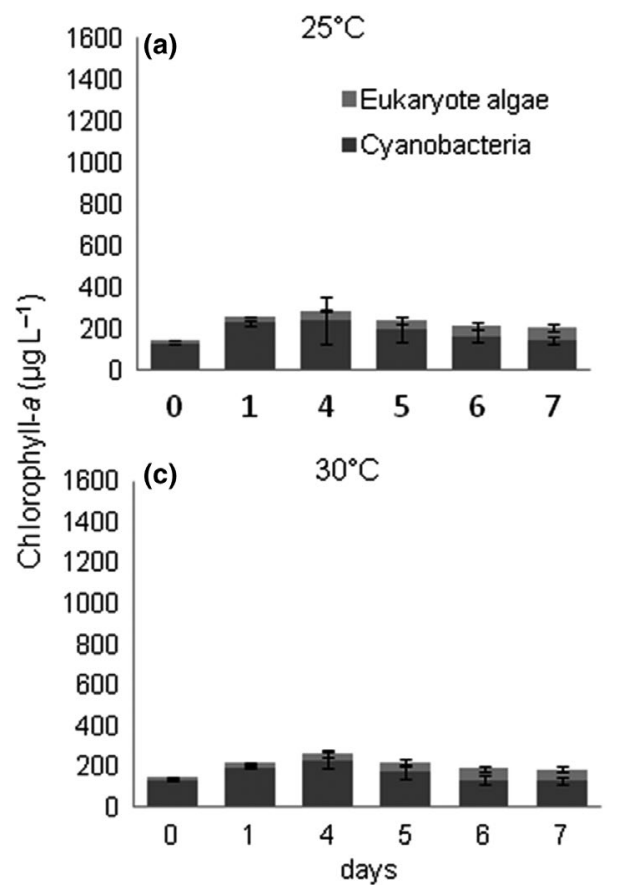

FIGURE 1 Eukaryote algae and Cyanobacteria biomass (expressed as chlorophyll-a concentration) in experiments with eutrophic system phytoplankton community (error bars indicate plus or minus one standard error)

\section{2 | Data analysis}

The natural log transformed response ratio $\left(R_{\mathrm{x}}\right)$ was used as a metric of the size effect of temperature and nutrient additions on cyanobacteria and eukaryotic algae growth rate. The response ratio of cyanobacteria $\left(R R_{\text {cyano }}\right)$ and eukaryote algae $\left(R R_{\text {algae }}\right)$ was calculated as the ratio between the growth rate of each treatment $T\left(30^{\circ} \mathrm{C}\right.$, $25^{\circ} \mathrm{C} \mathrm{N}+\mathrm{P}$ and $30^{\circ} \mathrm{C} \mathrm{N}+\mathrm{P}$ ) and the growth rate in the sole $25^{\circ} \mathrm{C}$ incubations (used as control, $C$ ) following $R_{x}=\ln (T / C$ ) (Elser et al. 2007) for eutrophic water systems. The growth rate in the sole $30^{\circ} \mathrm{C}$ incubations was used as a control $(C)$ for the oligo-mesotrophic system, however, since the $30^{\circ} \mathrm{C}$ temperature was closest to the annual average water temperature of this system. A two-way ANOVA with water. 
different trophic state systems (eutrophic and oligo-mesotrophic) and phytoplankton groups (cyanobacteria and eukaryote algae) as fixed factors was performed to test whether or not temperature and nutrient additions affected the response ratios of cyanobacteria and eukaryotic algae. All the statistical analysis was performed using tool pack SigmaPlot, Version 12 (Systat Software, Inc).

\section{3 | RESULTS}

\subsection{Effect of temperature variations and eutrophication on tropical phytoplankton communities}

The $5^{\circ} \mathrm{C}$ temperature variation was not an important factor in changing the phytoplankton composition in both experimental conditions with water from the eutrophic and oligo-mesotrophic system (Figures 1a,c, 2a,c. At the beginning of the experiment, the phytoplankton community of the eutrophic system was dominated by cyanobacteria (mean value of all treatments $=88 \%$ of total biomass) with an average biomass of $127 \mu \mathrm{g}$ chlorophyll- $a / \mathrm{L}$. At the end of the experiment, cyanobacteria (mean $=70 \%$ ) remained dominant over eukaryote algae (mean $=30 \%$ ) in both treatments, $25^{\circ} \mathrm{C}$ and $30^{\circ} \mathrm{C}$ (Table 2). The biomass of these treatments never exceeded $250 \mu \mathrm{g} / \mathrm{L}$ for cyanobacteria and $60 \mu \mathrm{g} / \mathrm{L}$ for eukaryote algae over the entire experimental period (Figure 1a,c). Further, when nutrients were added, cyanobacteria remained dominant (mean $=97.3 \%$ ). In contrast, nutrient additions boosted cyanobacteria biomass, which increased from $124.1( \pm 1.9) \mu \mathrm{g} / \mathrm{L}$ to $1,331.7( \pm 48.9) \mu \mathrm{g} / \mathrm{L}$ in the $25^{\circ} \mathrm{C}$ $\mathrm{N}+\mathrm{P}$ treatment, and from $125.3( \pm 4.53) \mu \mathrm{g} / \mathrm{L}$ to $1,264.0( \pm 124.0)$ $\mu \mathrm{g} / \mathrm{L}$ in the $30^{\circ} \mathrm{C} \mathrm{N}+\mathrm{P}$ treatment (Figure $1 \mathrm{~b}, \mathrm{~d}$; Table 2).

In water from the oligo-mesotrophic system at the start of the experiment, eukaryote algae were more abundant (mean contribution for all treatments $=66.4 \%$ ) than cyanobacteria (mean for all treatments $=33.6 \%$ ). The share of cyanobacteria in the phytoplankton community during the first three days of the experimental period increased in all treatments, reaching about $50 \%$, maintaining this level until the end of the experiment (Figure 2a,c). The temperature variation from $25^{\circ} \mathrm{C}$ to $30^{\circ} \mathrm{C}$ did not change the contribution of phytoplankton groups and total biomass without nutrient additions, which remained $<20 \mu \mathrm{g}$ chlorophyll-a/L(Figure 2a,c). Nutrient addition caused a small increase to about $30 \mu \mathrm{g} / \mathrm{L}$ in the $30^{\circ} \mathrm{C} \mathrm{N}+\mathrm{P}$ treatments (Figure $2 \mathrm{~d}$ ), and a stronger increase from 11 to $60 \mu \mathrm{g} / \mathrm{L}$ in the $25^{\circ} \mathrm{C} \mathrm{N}+\mathrm{P}$ treatments (Figure $2 \mathrm{~b}$; Table 2).

Warming in itself led to negative response ratios for both cyanobacteria $\left(R R_{\text {cyano }}\right)$ and eukaryote algae $\left(R R_{\text {algae }}\right)$ in water from the oligo-mesotrophic as well as the eutrophic system (Figure 3), reflecting a decrease in biomass compared to the sole $25^{\circ} \mathrm{C}$ incubations. No significant difference was observed between $R R_{\text {cyano }}$ and $R_{\text {algae }}$ eutrophic system for the $\mathrm{e} 30^{\circ} \mathrm{C}$ treatment $(p=0.807)$.

Nutrient additions either alone $\left(25^{\circ} \mathrm{C} \mathrm{N}+\mathrm{P}\right)$ or in combination with higher temperature $\left(30^{\circ} \mathrm{C} \mathrm{N}+\mathrm{P}\right)$, however, resulted in different responses in water from the eutrophic and oligo-mesotrophic system (Figure 3). Nutrient addition to water from the eutrophic system resulted in a strong cyanobacteria response ratio, while the eukaryote algae continued to exhibit a negative response ratio. The elevated temperature and nutrient addition $\left(30^{\circ} \mathrm{C} \mathrm{N}+\mathrm{P}\right)$ intensified the negative response ratio of the eukaryote algae. The $R_{\text {cyano }}$ was significantly higher than the $\operatorname{RR}_{\text {algae }}(p=.002)$. In contrast, $\operatorname{RR}_{\text {algae }}$ in water from the oligo-mesotrophic system were positive in both in nutrient enriched treatments $\left(25^{\circ} \mathrm{C} \mathrm{N}+\mathrm{P}\right.$ and $30^{\circ} \mathrm{C} \mathrm{N}+\mathrm{P}$; Figure 3), but were significantly higher than $R_{\text {cyano }}$ only in the $25^{\circ} \mathrm{C} \mathrm{N}+\mathrm{P}$ treatment $(p<.001)$. Nutrient addition led to a weaker positive $\mathrm{RR}_{\text {cyano }}$ in the oligo-mesotrophic water, compared to the eutrophic water (Figure 3).
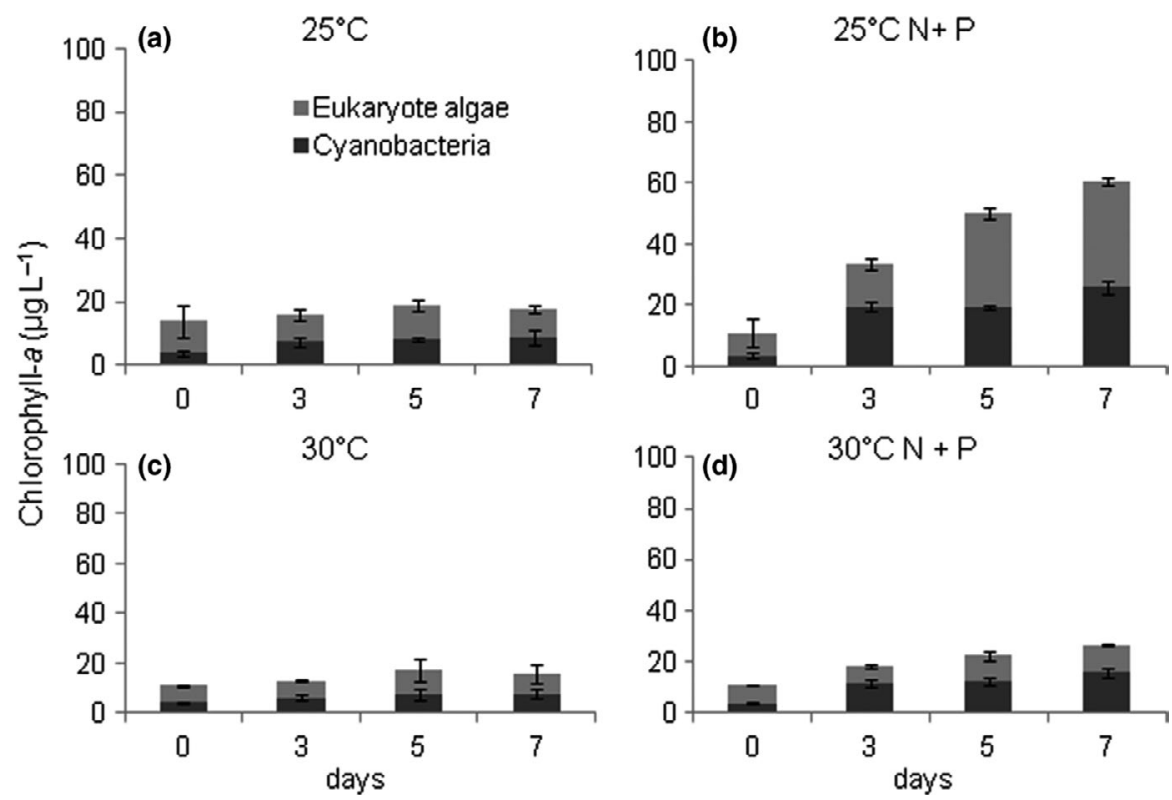

FIGURE 2 Eukaryote algae and Cyanobacteria biomass (expressed as chlorophyll-a concentration) in experiments with oligo-mesotrophic system phytoplankton community (error bars indicate plus or minus one standard error) 
TABLE 2 Biomass (chlorophyll-a) and relative abundance of Cyanobacteria and Eukaryote algae at beginning and end of experimental period

\begin{tabular}{|c|c|c|c|c|c|}
\hline \multirow[b]{2}{*}{ Treatment } & \multirow[b]{2}{*}{ Days } & \multicolumn{2}{|l|}{ Eukaryote algae } & \multicolumn{2}{|l|}{ Cyanobacteria } \\
\hline & & Biomass (Chl- $a \mu \mathrm{g} / \mathrm{L}$ ) & $\%$ & Biomass (Chl- $a \mu \mathrm{g} / \mathrm{L})$ & $\%$ \\
\hline \multicolumn{6}{|c|}{ OLIGO-MESOTROPHIC SYSTEM } \\
\hline \multirow[t]{2}{*}{$25^{\circ} \mathrm{C}$} & 0 & 10.02 & 71.7 & 3.96 & 28.3 \\
\hline & 7 & 8.87 & 50.2 & 8.80 & 49.8 \\
\hline \multirow[t]{2}{*}{$25^{\circ} \mathrm{CN}+\mathrm{P}$} & 0 & 7.34 & 66.7 & 3.66 & 33.3 \\
\hline & 7 & 34.59 & 57.1 & 25.98 & 42.9 \\
\hline \multirow[t]{2}{*}{$30^{\circ} \mathrm{C}$} & 0 & 6.98 & 63.0 & 4.10 & 37.0 \\
\hline & 7 & 8.10 & 51.0 & 7.79 & 49.0 \\
\hline \multirow[t]{2}{*}{$30^{\circ} \mathrm{CN}+\mathrm{P}$} & 0 & 7.18 & 64.2 & 4.00 & 35.8 \\
\hline & 7 & 10.97 & 41.0 & 15.77 & 59.0 \\
\hline \multicolumn{6}{|c|}{ EUTROPHIC SYSTEM } \\
\hline \multirow[t]{2}{*}{$25^{\circ} \mathrm{C}$} & 0 & 17.9 & 12.4 & 127.0 & 87.6 \\
\hline & 7 & 60.1 & 29.4 & 144.1 & 70.6 \\
\hline \multirow[t]{2}{*}{$25^{\circ} \mathrm{CN}+\mathrm{P}$} & 0 & 16.8 & 11.9 & 124.1 & 88.1 \\
\hline & 7 & 51.7 & 4.2 & 1190.1 & 95.8 \\
\hline \multirow[t]{2}{*}{$30^{\circ} \mathrm{C}$} & 0 & 16.4 & 11.2 & 130.0 & 88.8 \\
\hline & 7 & 56.8 & 30.2 & 131.3 & 69.8 \\
\hline \multirow[t]{2}{*}{$30^{\circ} \mathrm{CN}+\mathrm{P}$} & 0 & 16.2 & 11.4 & 125.0 & 88.6 \\
\hline & 7 & 13.4 & 1.3 & 993.0 & 98.7 \\
\hline
\end{tabular}

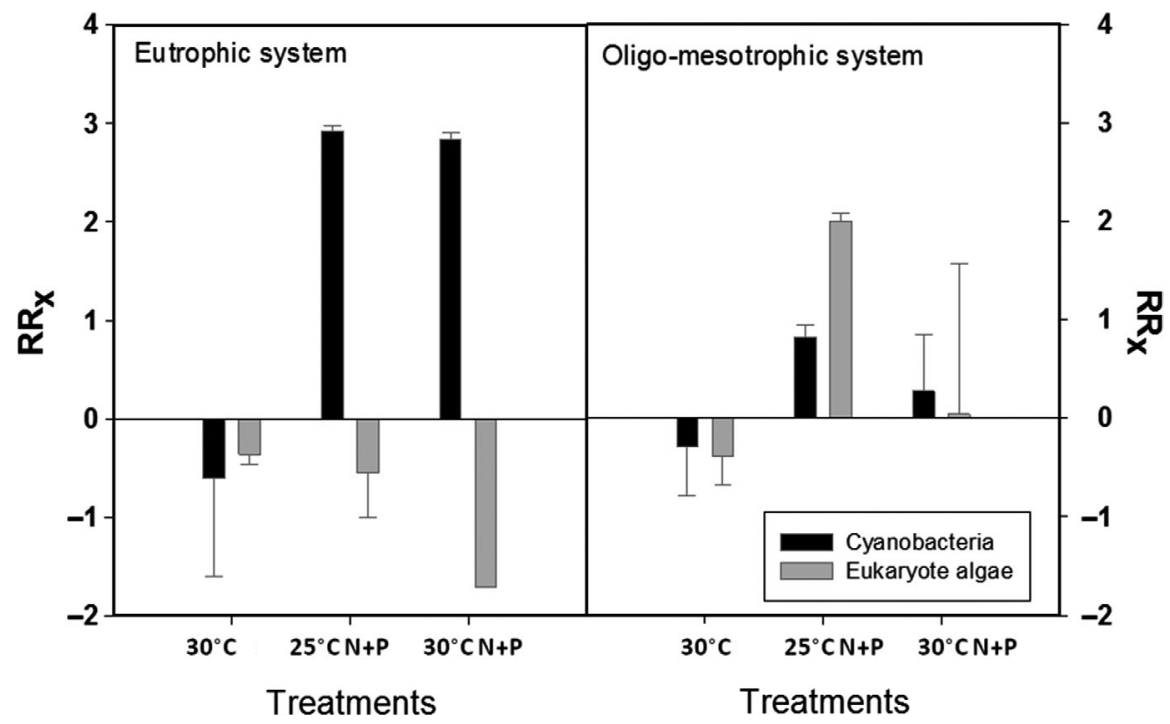

FIGURE 3 Response ratio of cyanobacteria and eukaryotic algae growth rate to each treatment $\left(25^{\circ} \mathrm{C}\right.$, $30^{\circ} \mathrm{C}, 25^{\circ} \mathrm{C} \mathrm{N}+\mathrm{P}$ and $3^{\circ} \mathrm{C} \mathrm{N}+\mathrm{P}$ ) in eutrophic system and oligo-mesotrophic system experiments (error bars indicate plus or minus one standard error)

\section{DISCUSSION}

\subsection{What is the effect of temperature and} eutrophication on phytoplankton communities in tropical ecosystems exhibiting different trophic states?

The results of the present study clearly indicated that temperature alone did not lead to higher cyanobacteria biomass in the experiments with water from an oligo-mesotrophic and eutrophic system. In fact, the response ratios were negative, meaning the phytoplankton biomass declined in eutrophic system. For the oligo-mesotrophic system, the small phytoplankton biomass increase at $25^{\circ} \mathrm{C}$ seems to indicate higher temperatures can promote damage in the phytoplankton community. Thus, the significance of a direct warming effect on freshwater phytoplankton, and particularly on stimulating cyanobacteria growths, may be questioned. It seems more likely that indirect effects of warming (increased thermal stratification and water column stability) will promote cyanobacteria (with buoyancy control) over non-flagellate eukaryote 
algae (Carey et al. 2012). Nevertheless, the most important driver of cyanobacteria blooms by far is increased nutrient concentrations (Brookes and Carey, 2011).

The present study demonstrated that adding extra nutrients resulted in a higher phytoplankton biomass in water from both the oligo-mesotrophic and the eutrophic systems. The response was much stronger in the water from the eutrophic system, with the cyanobacteria biomass increasing to very high levels. There was no synergism, however, between the nutrient addition and the temperature in the cyanobacteria development, in contrast to a previous suggestion that this synergism played a role in eutrophic and hyper-eutrophic systems (Rigosi et al. 2014). The present study also demonstrated that, under high nutrient conditions, no evidence of a temperature effect on cyanobacteria biomass was observed. Nonetheless, the results provide further evidence that eutrophic lakes with cyanobacterial blooms can also be sensitive to nutrient pulses, causing a further increase in cyanobacteria biomass and creating an even worse scenario. In high-nutrient systems, light might become a limiting factor steering cyanobacteria development (Rigosi et al. 2014). Yet some cyanobacteria species (e.g., Planktothrix agardhii) are particularly equipped to thrive under such conditions (Reynolds and Huszar, 2002).

The different responses to nutrient additions between the water from the oligo-mesotrophic and the eutrophic system underpin that lowering the nutrient status of lakes will render them less vulnerable to the predicted effects of global changes (Brookes and Carey, 2011). These are likely the indirect effects that favour cyanobacteria biomass accumulation either at the water surface as a consequence of water column stability, or when populations are fuelled from enhanced internal nutrient release and pulsed nutrient additions following precipitation. Such indirect effects may actually be more important than the direct effects on growth (Carey et al. 2012; Lürling et al. 2013). Thus, the lower biomass observed in water from the oligo-mesotrophic systems seems to enhance resistance against nutrient pulses, as evident from the lower $R_{\text {cyano }}$ found in the present study.

The share of cyanobacteria comprising the phytoplankton community was lower in water from the oligo-mesotrophic system than in water from the eutrophic system, as expected from the general tendency of cyanobacteria dominance in eutrophic systems (Watson et al. 1997). In a shallow lake survey spanning several climate regions, temperature was identified as the single most explanatory variable of the percent cyanobacteria in the phytoplankton community (Kosten et al. 2012). The results of the present study, however, did not produce an increase in the share of cyanobacteria when water from either the oligo-mesotrophic or the eutrophic system was incubated at higher temperatures. Although the eutrophic water was already dominated by cyanobacteria ( $88 \%)$, nutrients rather than warming, further stimulated cyanobacteria contribution to $97 \%$ of the total phytoplankton. Likewise, temperature variations alone had no significant effect on the share of cyanobacteria in water from the oligo-mesotrophic system. Microcystis spp. were the only cyanobacteria in both the oligo-mesotrophic and eutrophic systems at the end of the incubation. This was not surprising since $M$. aeruginosa and M. panniformes were reported as dominant species in cyanobacterial blooms in Jacarepaguá Lagoon and Samuel Reservoir, respectively.

The existence of oligotrophic and mesotrophic reservoirs in Brazil that are devoid of nuisance blooms (Lopes et al. 2005; Soares et al. 2008), in close proximity to eutrophic reservoirs suffering from cyanobacterial blooms (Marinho and Huszar, 2002; Molisani et al. 2010; Rangel et al. 2012, Soares et al. 2008, 2009), highlights that warmer temperature alone is not a key driver of cyanobacterial blooms, at least in the study region. Several studies have addressed the indirect effects of climate change, although nutrient loading may be more important than the direct effects of temperature increases (Carey et al. 2012; De Senerpont Domis et al. 2013), pointing to eutrophication as a primary factor. Indeed, higher nutrient availability will allow more biomass build-up, whereas pulsed fluxes after short, intense storms that increase soil erosion will further fuel cyanobacterial blooms (Moss et al. 2011). In addition, warmer temperature could lead to more water column stability, thereby promoting cyanobacterial nuisance as is evidenced in previous studies indicating that cyanobacterial nuisance in typical heat wave years depended on water column stability (Huber et al. 2012; Jöhnk et al. 2008). Water column stability was not included as a factor in the present study since the flasks were shaken twice daily. This did not hamper cyanobacteria growth at all, however, since strong cyanobacteria increases in the nutrient-enriched eutrophic water treatments were observed. Nevertheless, water column stability is an important factor. Even in oligo-mesotrophic lakes with low water column cyanobacteria biomass, wind-driven cyanobacteria scum accumulation may occur at certain nearshore sites, while the open waters may be quite clear (Johnston and Jacoby, 2003). Both aspects of warming, including water column stability-driven surface accumulation and enhanced nutrient loading, should forewarn water authorities of the important need for strong eutrophication control since only very low cyanobacteria biomasses will facilitate non-hazardous water conditions. In fact, this may be more necessary in tropical areas since tropical waters tend to be more vulnerable to eutrophication than temperate systems; namely because at elevated temperatures in shallow lakes the loss of submerged vegetation and a switch to cyanobacteria might occur at lower nutrient concentrations (Kosten et al. 2009). Thus, reduced nutrient inputs are not only relevant to counteract indirect climate warming consequences in temperate shallow lakes (Jeppesen et al. 2003), but also are relevant for tropical lakes.

\section{5 | CONCLUSION}

A widely held belief within the scientific community is that global warming and corresponding increases in water temperatures will promote cyanobacteria blooms. The present study, however, suggests an increase in water temperature alone is not necessarily the case because the results demonstrate that warming alone does not significantly change the phytoplankton community. Rather, the process of eutrophication contributes more to such changes than 
warming alone. Thus, it is important to emphasize that the complete scenario described during discussions about global warming and/or climate change events consider the holistic effects of those events to water bodies. In other words, these discussions should include not only temperature or nutrient increase effects alone, but also the complex interactions among relevant physical, chemical and biological parameters as well as the frequency and intensity of those 'pulses'. Further, water systems exhibiting different trophic states can respond to nutrient enrichment in different ways. Eutrophic water systems were shown to exhibit intensified cyanobacteria dominance when more nutrients were added. In contrast, oligo-mesotrophic systems exhibited a relatively bigger resistance to nutrient addition that did not cause a change in the phytoplankton groups composition during the experimental time. All groups of algae could be favoured by eutrophication, independent of a direct temperature effect. This suggests cyanobacteria dominance can be favoured by further nutrient additions in eutrophic water systems. Since global warming associated with extreme climatic events are assumed to indirectly intensify eutrophication symptoms, the results of the present study underscore the importance of proper water management by regulatory agencies regarding the control of nutrient content/inputs into water systems. In addition, governing bodies and regulatory agencies must work to preserve already pristine ecosystems where they exist. Further, the results of the present study also suggest the potential resilience observed in oligo-mesotrophic systems in tropical regions requires further study for a better understanding of their dynamics in regard to these factors.

\section{ACKNOWLEDGEMENTS}

The work was supported by grants from Fundação de Amparo a Pesquisa do Estado do Rio de Janeiro (FAPERJ) and was conducted under auspices of the CAPES (Brazil)/NUFFIC (The Netherlands) project 045/2012. A.M.A.G. was supported by Pos-doc fellowship from PAPDJ-CAPES/FAPERJ (proc. E-26/102.863/2011), Brazil.

\section{CONFLICTS OF INTEREST}

The authors declare no conflict of interest.

\section{ORCID}

Sandra M. F. O. Azevedo (iD https://orcid. org/0000-0002-3046-0652

\section{REFERENCES}

Brookes, J. D., \& Carey, C. C. (2011). Resilience to blooms. Ecology, 334 46-47.

Carey, C. C., Ibelings, B. W., Hoffmann, E. P., Hamilton, D. P., \& Brookes, J. D. (2012). Eco-physiological adaptations that favour freshwater cyanobacteria in a changing climate. Water Research, 46, 1394-407.

Carpenter, S., Fisher, S., Grimm, N., \& Kitchell, J. (1992). Global change and freshwater ecosystems. Annual. Reviews in Ecology, 23, 119-139.

Conley, D. J., Paerl, H. W., Howarth, R. W., Boesch, D. F., Seitzinger, S. P., Havens, K. E., ... Likens, G. E. (2009). Controlling eutrophication: Nitrogen and phosphorus. Science, 323, 1014-1015.
De Senerpont Domis, L. N., Mooij, W. M., \& Huisman, J. (2007). Climateinduced shifts in an experimental phytoplankton community: A mechanistic approach. Hydrobiologia, 584, 403-413.

De Senerpont Domis, L. N., Elser, J. J., Gsell, A. S., Huszar, V. L. M., Ibelings, B. W., Jeppesen, E., ... Lürling, M. (2013). Plankton dynamics under different climatic conditions in space and time. Freshwater Biology, 58, 463-482.

Elser, J. J., Bracken, M. E. S., Cleland, E. E., Gruner, D. S., Harpole, W. S., Hillebrand, H., ... Smith, J. E. (2007). Global analysis of nitrogen and phosphorus limitation of primary producers in freshwater, marine and terrestrial ecosystems. Ecology Letters, 10, 1135-42.

Ferrão-Filho, A. S., Domingos, P., \& Azevedo, S. M. F. D. O. E. (2002). Influences of a Microcystis aeruginosa Kutzing bloom on zooplankton populations in Jacarepagua Lagoon (Rio de Janeiro, Brazil). Limnology - Ecology and Management of Inland Waters, 32, 295-308.

Gomes, A., Sampaio, P., Ferrão-Filho, A. S., Magalhaes, V. F., Manzi, M., Oliveira, A., ... Azevedo, S. M. F. O. (2009). Florações de cianobactérias tóxicas em uma lagoa costeira hipereutrófica do Rio de Janeiro/ RJ (Brasil) e suas consequências para saúde humana. Oecologia Bras, 13, 329-345.

Hansen, J., Sato, M., Ruedy, R., Lacis, A., \& Oinas, V. (2000). Global warming in the twenty-first century: An alternative scenario. Proceedings of the National Academy of Science, USA, 97, 9875-80.

Huber, V., Wagner, C., Gerten, D., \& Adrian, R. (2012). To bloom or not to bloom: Contrasting responses of cyanobacteria to recent heat waves explained by critical thresholds of abiotic drivers. Oecologia, $169,245-56$.

Jeppesen, E., Sondergaard, M., \& Jensen, J. P. (2003). Climatic warming and regime shifts in lake food webs-some comments. Limnology \& Oceanography, 48, 1346-1349.

Jöhnk, K., Huisman, J., Sharples, J., Sommeijer, B., Visser, P., \& Strooms, J. (2008). Summer heatwaves promote blooms of harmful cyanobacteria. Global Change Biology, 14, 495-512.

Johnston, B. R., \& Jacoby, J. M. (2003). Cyanobacterial toxicity and migration in a mesotrophic lake in western Washington, USA. Hydrobiologia, 495, 79-91.

Kosten, S., Kamarainen, A., Jeppesen, E., Van Nes, E. H., Peeters, E. T. H. M., Mazzeo, N., ... Scheffer, M. (2009). Climate-related differences in the dominance of submerged macrophytes in shallow lakes. Global Change Biology, 15, 2503-2517.

Kosten, S., Huszar, V. L. M., Bécares, E., Costa, L. S., Donk, E., Hansson, L.-A., ... Scheffer, M. (2012). Warmer climates boost cyanobacterial dominance in shallow lakes. Global Change Biology, 18, 118-126.

Lopes, M. R. M., Bicudo, C. E. D. M., \& Ferragut, M. C. (2005). Short term spatial and temporal variation of phytoplankton in a shallow tropical oligotrophic reservoir, southeast Brazil. Hydrobiologia, 542, 235-247.

Lürling, M., Eshetu, F., Faassen, E. J., Kosten, S., \& Huszar, V. L. M. (2013). Comparison of cyanobacterial and green algal growth rates at different temperatures. Freshwater Biology, 58, 552-559.

Magalhães, V. F., Soares, R. M., \& Azevedo, S. M. F. O. (2001). Microcystin contamination in fish from the Jacarepaguá Lagoon (Rio de Janeiro, Brazil): Ecological implication and human health risk. Toxicon, 39, 1077-1085.

Marinho, M., \& Huszar, V. L. M. (2002). Nutrient availability and physical conditions as controlling factors of phytoplankton composition and biomass in tropical reservoir. Archiv. fuer Hydrobiologie, 153, 443-468.

Molisani, M. M., Barroso, H. D. S., Becker, H., Moreira, M. O. P., Hijo, C. A. G., Monte, T. M., \& Vasconcellos, G. H. (2010). Trophic state, phytoplankton assemblages and limnological diagnosis of the Castanhão Reservoir, CE, Brazil. Acta Limnologica Brasiliensia, 22, 1-12.

Moss, B., Kosten, S., Meerhof, M., Battarbee, R. W., Jeppesen, E., Mazzeo, N., ... Scheffer, M. (2011). Allied attack: climate change and eutrophication. Inland Waters, 101-105. 
Nascimento, E. L. (2012). Fatores ambientais reguladores da dinâmica de cianobactérias no reservatório da Usina Hidrelétrica de Samuel, Rondônia (Amazonia Ocidental, Brasil). PhD Thesis approved by Graduate Program of Carlos Chagas Filho Institute of Biophysics of the Federal University of Rio de Janeiro. p. 187.

O'Neil, J. M., Davis, T. W., Burford, M. A., \& Gobler, C. J. (2012). The rise of harmful cyanobacteria blooms: The potential roles of eutrophication and climate change. Harmful Algae, 14, 313-334.

Paerl, H., \& Huisman, J. (2008). Blooms like it hot. Science, 320, 57-58.

Paerl, H. W., \& Huisman, H. (2009). Climate change: a catalyst for global expansion of harmful cyanobacterial blooms. Environmental Microbiology Reports, 1, 27-37.

Paerl, H. W., \& Paul, V. J. (2012). Climate change: Links to global expansion of harmful cyanobacteria. Water Research, 46, 1349-63.

Rangel, L., Silva, L., Rosa, P., Roland, F., \& Huszar, V. (2012). Phytoplankton biomass is mainly controlled by hydrology and phosphorus concentrations in tropical hydroelectric reservoirs. Hydrobiologia, 693, 13-28.

Reynolds, C., \& Huszar, V. (2002). Towards a functional classification of the freshwater phytoplankton. Journal of Plankton Research, 24, 417-428.

Rigosi, A., Carey, C. C., Ibelings, B. W., \& Brookes, J. D. (2014). The interaction between climate warming and eutrophication to promote cyanobacteria is dependent on trophic state and varies among taxa. Limnology \& Oceanography, 59, 99-114.

Saieg-Filho, E. (1986). Ecologia do Fitoplâncton Marginal do Complexo Lagunar da Baixada de Jacarepaguá. Bachelor's degree monograph. Biology Institute. Staty University of Rio de Janeiro (150 p).
Soares, M. C. S., Marinho, M. M., Huszar, V. L. M., Branco, C. W. C., \& Azevedo, S. M. F. O. (2008). The effects of water retention time and watershed features on the limnology of two tropical reservoirs in Brazil. Lakes \& Reservoirs: Research and Management, 13, 257-269.

Soares, M., de A Rocha, M., Marinho, M., Azevedo, S., Branco, C., \& Huszar, V. (2009). Changes in species composition during annual cyanobacterial dominance in a tropical reservoir: Physical factors, nutrients and grazing effects. Aquatic Microbiology and Ecology, 57, 137-149.

Tilman, D., \& Lehman, C. (2001). Human-caused environmental change: impacts on plant diversity and evolution. Proceedings of National Academy of Science, USA, 98, 5433-40.

Watson, S. B., McCauley, E., \& Downing, J. A. (1997). Patterns in phytoplankton taxo- nomic composition across temperate lakes of differing nutrient status. Limnology \& Oceanography, 42, 487-495.

How to cite this article: Gomes AMA, Marinho MM, Berjante Mesquita MC, Prestes ACC, Lürling M, Azevedo SMFO. Warming and eutrophication effects on the phytoplankton communities of two tropical water systems of different trophic states: An experimental approach. Lakes \& Reserv. 2020;25:275-282. https://doi.org/10.1111//re.12334 